\title{
Phosphorus flux by macrobenthic invertebrates in a shallow eutrophic lake Donghu: spatial change
}

\author{
L. Ji( ${ }^{(1,2)}$, N.A. Berezina ${ }^{(3)}$, S.M. Golubkov ${ }^{(3)}$, X. Cao $^{(1)}$, M.S. Golubkov ${ }^{(3)}$, \\ C. Song ${ }^{(1)}$, L.P. Umnova ${ }^{(3)}, Y$. Zhou ${ }^{(1)}$
}

Received February 1st, 2011

Revised July 6, 2011

Accepted July 27, 2011

\section{ABSTRACT}

Key-words: $\quad$ We estimated phosphorus flux mediated by benthic invertebrates from the phosphorus, excretion, zoobenthos, spatial distribution, shallow lake sediments to the water in a shallow eutrophic lake (lake Donghu, central China) and quantified spatial (littoral and central sites) and specific (among different benthic taxa) differences. The mass-specific excretion rates of phosphorus (soluble reactive phosphorus (SRP, nmol $\cdot \mathrm{mg}$ dry mass ${ }^{-1} \cdot \mathrm{h}^{-1}$ ) by benthic invertebrates (abundant taxa) were estimated experimentally and calculated as a final minus of initial nutrient mass divided by dry mass of organisms. Results showed high importance of chironomid larvae as a contributor to the total $P$ flux from sediments to water in shallow lake Donghu. Benthic biomass (from 0.002 to $32.8 \mathrm{~g}$ dry mass $\cdot \mathrm{m}^{-2}$ ) distribution and species composition (31 taxa) were studied (October 2009) in three regions of lake Donghu (Guozhenghu, Miaohu, Yujiahu) using samples from three depths: the shallow littoral site (0.2-1 m depth), central site with $2 \mathrm{~m}$ depth, and central site with more than $3 \mathrm{~m}$ depth. The total estimated SRP excretion by benthic invertebrate reaches $36 \%$ of the direct SPR flux from sediments to water in this lake. The phosphorus regeneration by benthic animals is the most intensive in the shallow littoral sites $(69.5 \mu \mathrm{mol}$ $\mathrm{P} \cdot \mathrm{m}^{-2} \cdot$ day $\left.^{-1}\right)$ and at least 20 times greater than in central sites $(3.4 \mu \mathrm{mol}$ $\left.\mathrm{P} \cdot \mathrm{m}^{-2} \cdot \mathrm{day}^{-1}\right)$ of lake Donghu. The results support notable differences in the SRP excretion rates between taxa and sites. The spatial difference in the SRP flux might be considered as a general feature of lakes with periodical changing oxygen near bottom.

RÉSUMÉ

Flux de phosphore dû aux invertébrés macrobenthiques dans un lac peu profond et eutrophe, le lac Donghu.

Mots-clés : $\quad$ Nous avons estimé le flux de phosphore des sédiments vers l'eau créé par les inphosphore, vertébrés benthiques dans un lac peu profond eutrophe (lac Donghu, centre de la excrétion, Chine) et quantifié les différences spatiales (sites du littoral et du centre) et spécizoobenthos, fiques (entre différents taxons benthiques). Les taux d'excrétion du phosphore (phosphore réactif soluble : SRP, nmol.mg de masse sèch $\mathrm{e}^{-1} \cdot \mathrm{h}^{-1}$ ) parles invertébrés

(1) Institute of Hydrobiology, Chinese Academy of Sciences, Wuhan 430072, Hubei, P.R. China, nber@zin.ru, zhouyy@ihc.ac.cn

(2) Graduate School, Chinese Academy of Sciences, Beijing 100049, P.R. China

(3) Zoological Institute, Russian Academy of Science, St. Petersburg 199034, Russia 
distribution spatiale, lac peu profond benthiques (taxons abondants) ont été estimés expérimentalement et calculés comme la différence entre masses de nutriment finale et initiale divisée par la masse sèche des organismes. Les résultats ont montré une grande importance des larves de chironomides en tant que contributeurs au flux de $P$ total de sédiments vers l'eau dans le lac peu profond Donghu. La distribution de la biomasse benthique (de 0,002 à $32,8 \mathrm{~g}$ de matière sèche $\cdot \mathrm{m}^{-2}$ ) et sa composition spécifique (31 taxons) ont été étudiées (octobre 2009) dans trois régions du lac Donghu (Guozhenghu, Miaohu, Yujiahu) en utilisant des échantillons provenant de trois profondeurs : le site peu profond du littoral $(0,2-1 \mathrm{~m}$ de profondeur), le site central avec $2 \mathrm{~m}$ de profondeur, et le site central avec plus de $3 \mathrm{~m}$ de profondeur. L'excrétion SRP totale estimée pour les invertébrés benthiques atteint $36 \%$ du flux direct de SRP des sédiments vers l'eau dans ce lac. La régénération du phosphore par les animaux benthiques est la plus intense dans les sites peu profonds du littoral $\left(69,5 \mathrm{pmol} \mathrm{P} \cdot \mathrm{m}^{-2}\right.$.jour $\left.{ }^{-1}\right)$ et au moins 20 fois plus importante que dans les sites centraux $\left(3,4 \mathrm{~mol} \mathrm{P} \cdot \mathrm{m}^{-2}\right.$.jour $\left.{ }^{-1}\right)$ du lac Donghu. Les résultats confirment des différences notables dans les taux d'excrétion SRP entre les taxons et les sites. La différence spatiale dans le flux SRP pourrait être considérée comme une caractéristique générale des lacs avec des changements périodiques de concentration en oxygène près du fond.

\section{INTRODUCTION}

Phosphorus cycling may be defined as the transformation of nutrients from one chemical form to another, and/or as the flux of nutrients between organisms, habitats, or ecosystems. Phosphorus can be released from sediments through a variety of mechanisms, including activities of benthic animals. A lot of studies have confirmed important regulating role of benthic invertebrates in nutrient cycling by different mechanisms such as bioturbation, vertical migration and direct excretion (Andersson et al., 1988; Vanni, 2002; Griffiths, 2006).

According to Vanni (2002), aquatic animals excrete phosphorus directly by egestion, releasing particulate phosphorus with feces and dissolved phosphorus with urine. In this case, the phosphorus release rate is a function between the nutrient contents in the animals' body and in their food. Also, assimilated with food phosphorus is partly used for somatic growth; therefore a significant proportion of it is contained in benthic biomass and may include later in the total lake cycling through trophic interactions.

Aquatic animals release phosphorus in the dissolved form of soluble reactive orthophosphates (SRP), which is almost completely available for algae (Vanni et al., 2001). In comparison, a large part of phosphorus originated from the external sources enters aquatic system in a particulate form poorly available to producers (algae). When ambient available phosphorus is scarce, bacterio- and phytoplankton can produce extracellular alkaline phosphotase to hydrolyze organic phosphorus for compensation of its deficiency (Feuillade et al., 1990; Spijkerman and Coesel, 1998; Gillor et al., 2002; Cao et al., 2005). Also, it had been showed that some aquatic animals affect the activity of the alkaline phosphotase (Vrba and Machacek, 1994).

In spite of high interest to the role of aquatic animals in nutrient cycling in lakes, their contribution to the total phosphorus flux is not estimated quantitatively, particularly in eutrophic ecosystems. There is not enough information about spatial variability in phosphorus flux mediated by different species/taxa of zoobenthos. It is expected that spatial differences in P flux via benthic community might be found in an eutrophic lake with variable environmental conditions in water near bottom and irregular distribution of benthic biomass. Also, specific differences in the phosphorus excretion rate between benthic taxa might be important. For example, nektobenthic amphipods (Gammarus lacustris) release notably higher portion of phosphorus (Wilhelm et al., 1999) than infaunal chironomid larvae when they often do not influence directly the phosphorus content in water near the bottom (Tarvainen et al., 2005).

Xie (2006) reported about close relationships between internal phosphorus loading and algal blooms in the shallow eutrophic lake Donghu (central China). We conducted this study in lake Donghu to estimate phosphorus flux mediated by benthic invertebrates from the bottom 


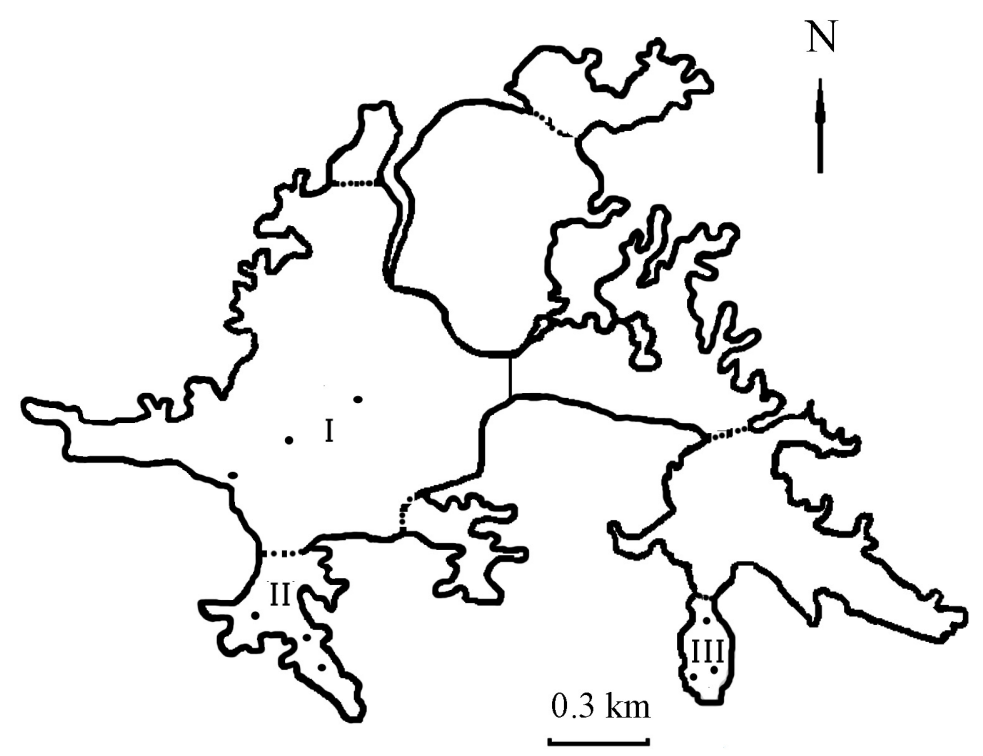

Figure 1

Map of lake Donghu with indicted study regions: I-Guozhenghu, II-Miaohu, III-Yujiahu. Location of sampling sites made as points.

Figure 1

Carte du lac Donghu avec les régions d'étude : I-Guozhenghu, II-Miaohu, III-Yujiahu. Localisation des sites d'échantillonnage indiquée par les points.

sediments to the water. Another important goal was to quantify spatial (in littoral and central sites) and specific (between benthic taxa) differences in SRP fluxes mediated by benthic animals.

\section{MATERIAL AND METHODS}

\section{> STUDY SITE}

Lake Donghu (mean depth $2.5 \mathrm{~m}$; max depth $4.5 \mathrm{~m}$ ) is a subtropical shallow lake $\left(30^{\circ} 33^{\prime} \mathrm{N}\right.$, $\left.114^{\circ} 23^{\prime} \mathrm{E}\right)$ with a total surface area of $32 \mathrm{~km}^{2}$ and a catchment area of $187 \mathrm{~km}^{2}$. Lake Donghu is a natural dammed lake formed in the early Holocene as a so-called "lateral lake". It is located in the middle reaches of the Changjiang (Yangtze) river ( $5 \mathrm{~km}$ away from the river). As a result of multiple uses (water supply, commercial fishery, and recreation) lake Donghu has been segmented into several parts by causeways across the lake proper and the bays (still allowing the passage of water between adjacent parts through a watercourse) since 1960s. Many small bays were separated from the main parts of the lake and used for artificial stocking of fish (Figure 1). We studied benthic communities at three sites in main parts of the lake such as Guozhenghu, Miaohu and Yujiahu (Figure 1).

Table I summarizes the basic physical and chemical characteristics of lake Donghu. The total salt content in water of the lake varied between 150 and $250 \mathrm{mg} \cdot \mathrm{L}^{-1}$. The $\mathrm{pH}$ of water ranged from 7 to 8.3. lake Donghu is subject to eutrophication due to domestic (80-90\%) and industrial (10-20\%) waste waters with large amounts of the total nitrogen and phosphorus. According to Xie (2006), the total phosphorus in lake Donghu was relatively low in the $1960 \mathrm{~s}\left(<0.05 \mathrm{mg} \cdot \mathrm{L}^{-1}\right)$, but it reached the maximum in $1980 \mathrm{~s}\left(0.22 \mathrm{mg} \cdot \mathrm{L}^{-1}\right)$ and declined sharply by $2000 \mathrm{~s}\left(0.08 \mathrm{mg} \cdot \mathrm{L}^{-1}\right)$. Before the 1970s, the aquatic plants were abundant and the coverage rate reached $40-80 \%$ 
Table I

Chemical characteristics of the lake Donghu (according to Huang, 1996; Li et al., 1996; Cao et al., 2005; Jiang and Shen, 2006 and our data).

Tableau I

Caractéristiques chimiques du lac Donghu (selon Huang, 1996 ; Li et al., 1996 ; Cao et al., 2005 ; Jiang et Shen, 2006 et nos données).

\begin{tabular}{|c|c|c|c|c|}
\hline Parameter & Donghu & Yujiahu & Miaohu & Guozhenghu \\
\hline Surface area $\left(\mathrm{km}^{2}\right)$ & $33.66 \pm 0.25$ & - & - & - \\
\hline Volume $\left(\times 10^{6} \mathrm{~km}^{3}\right)$ & $62 \pm 0.5$ & - & - & - \\
\hline Maximum depth (m) & $4.75 \pm 0.03$ & - & - & - \\
\hline Mean depth (m) & $2.2 \pm 0.01$ & - & - & - \\
\hline Level fluctuation (m) & $0.5 \pm 0.05$ & - & - & - \\
\hline Length of shoreline (km) & $9.2 \pm 0.10$ & - & - & - \\
\hline Residence time (a) & $0.44 \pm 0.01$ & - & - & - \\
\hline Catchment $\left(\mathrm{km}^{2}\right)$ & $97 \pm 1.2$ & - & - & - \\
\hline Transparency, cm & - & $60-80$ & $60-80$ & $50-70$ \\
\hline Dissolved oxygen, $\mathrm{mg} \cdot \mathrm{L}^{-1}$ & - & $5-9$ & $7-8.5$ & $6-8.5$ \\
\hline Chlorophyll A, $\mathrm{mg} \cdot \mathrm{m}^{-3}$ & - & $44-71$ & - & $15-106$ \\
\hline $\begin{array}{l}\text { Average temperature, }{ }^{\circ} \mathrm{C} \\
\text { Surface } \\
\text { Bottom }\end{array}$ & - & $\begin{array}{l}25.5 \\
24.1\end{array}$ & $\begin{array}{l}24.8 \\
24.9\end{array}$ & $\begin{array}{c}26 \\
22.4\end{array}$ \\
\hline $\mathrm{N}$ total, $\mathrm{mg} \cdot \mathrm{L}^{-1}$ & - & 1.52 & 2.18 & 1.44 \\
\hline$P$ total, $\mathrm{mg} \cdot \mathrm{L}^{-1}$ & - & 0.13 & 0.218 & 0.12 \\
\hline SRP $\mathbf{~ m g} \cdot \mathrm{L}^{-1}$ & - & 0.010 & 0.052 & 0.052 \\
\hline
\end{tabular}

of the sediment surface, but by the middle of 1990s they became very scarce (Li et al., 1996; Wang et al., 2000). During 2009 aquatic plants were also rarely found in all parts of lake Donghu. Over the year, the surface water temperature in the lake gradually increases from 15 to $20^{\circ} \mathrm{C}$ in March and then levels at $24-26^{\circ} \mathrm{C}$ in April-May. In June-August it varies between 25 and $35^{\circ} \mathrm{C}$, attaining maximum in July. It averages $20^{\circ} \mathrm{C}$ during September-October. In some cold years lake was ice-covered in January-February but usually winter water temperature does not drop below $5^{\circ} \mathrm{C}$.

Temperature stratification in the lake is usually not found during windy weather (late autumn, winter) due to active mixing by a strong wind action coupled with the convection of water. Dissolved oxygen (DO) content of the water column of lake Donghu in the pelagic zone averages $7.3 \mathrm{mg} \cdot \mathrm{L}^{-1}$. DO in areas near the bottom varied from $4.6-7.9 \mathrm{mg} \cdot \mathrm{L}^{-1}$.

Mid-summer, when surface water is calm and very warm (above $35^{\circ} \mathrm{C}$ ) strong thermal stratification develops in the lake, that may results temporarily in little oxygen in the hypolimnion/ water near the bottom $\left(3.4 \mathrm{mg} \cdot \mathrm{L}^{-1}\right)$ in different parts of the lake Donghu (Li et al., 1996; Wang et al., 2000).

Littoral (0-1 m depth) and central areas (>1-4.5 m depth) comprise $30 \%$ and $70 \%$ of the total lake area, respectively. Sediments are consisted of finely divided clays, mineral and organic matter in central sites while sand, stones, and relatively coarse materials (leaves, detritus) are typical substrates in littoral. 


\section{> SAMPLING}

In October 2009, we collected benthos to investigate biomass distribution and taxonomical composition. Samples were taken by Petersen's grab (sampling area $0.025 \mathrm{~m}^{2}$ ) and by frame $\left(20 \times 20 \mathrm{~cm}^{2}\right)$ from stones surface in three replicates at 9 sites in three regions of lake Donghu: Guozhenghu (30 32' N, 114 21' E; 0.5, 2, 3.5 m depths), Miaohu (30 33’ N, 114 22' E; 1, 2.5, $4 \mathrm{~m}$ ), and Yujiahu (Bay) (31 24' $\mathrm{N}, 120^{\circ} 11^{\prime} \mathrm{E}$; 0.5, 2 and $3 \mathrm{~m}$ ). The samples were sieved in a $0.25 \mathrm{~mm}$ mesh with the filtered water in plastic zip-bags and preserved with $4 \%$ formaldehyde. Also, benthic animals were collected in littoral $(0.5 \mathrm{~m})$ and central sites (2.5-3.5 m) at temperature $20^{\circ} \mathrm{C}$ for measurements of the SRP excretion rate in laboratory.

In laboratory all invertebrates were picked out the sampled sediments under stereoscopic microscope (MBS-10) and were sorted into diverse taxa: Oligochaeta, Hirudinea, Gastropoda, Bivalvia, Chironomidae, Coleoptera, Ceratopogonidae, and others. The animals were counted and weighed on an electro-balance to the nearest $0.01 \mathrm{mg}$. Prior weighting water was removed of animal body by filtered paper (wet weight, the shell of mollusks is included). To get dry weight, material was dried to constant weight at $60^{\circ} \mathrm{C}$ for $96 \mathrm{~h}$.

The biomass of benthic invertebrates were estimated as an arithmetical mean \pm SE (standard error) from all sampled replicates and then re-calculated per $1 \mathrm{~m}^{2}$ of bottom area. Like-wide biomass was re-calculated taking into account relative area (\%) of littoral $(<1 \mathrm{~m})$ and central $(>1 \mathrm{~m})$ parts. Possible differences in biomass of macroinvertebrates between sites were analyzed by one-way analysis of variance (ANOVA). Prior to the analysis, data were tested for homogeneity and then were $\lg (x+1)$ - transformed in the case of heterogeneous variances. If the overall ANOVA tests were significant, the Tukey HSD post-hoc test was performed to elucidate the pair-wise differences.

\section{> PHOSPHORUS EXCRETION EXPERIMENTS}

The excretion rates of phosphates (soluble reactive phosphorus, SRP) of benthic invertebrates were estimated at constant temperature $20^{\circ} \mathrm{C}$. In experiments we used freshly caught animals that were sampled in littoral and central sites of lake Donghu.

Dominating taxa of mollusks (Alocinma logicornis, Lymnaea sp.), oligochaetes (Limnodrillus hoffmeisteri) and chironomids (Chironomus plumosus, Tanypus chinensis) were used as tested organisms. Excretion rate was measured in each taxon alone. Experiments were carried out in 12-44 replicates for each species, using animals of in the size ranges: $0.04-0.13$ $\mathrm{g}$ dry weight in the case of molluscs, $0.01-0.018 \mathrm{~g}$ dry weight (oligochaetes) and 0.0003-0.002 g dry weight (chironomids). We put from 3 to 20 individuals of each taxon increasing the number from larger to smaller individuals.

The animals of each taxon were put in $50-70 \mathrm{ml}$ bottles filled with filtered natural water (through a $0.45 \mu \mathrm{m}$ pore size filter) and were incubated during $4 \mathrm{~h}$ at temperature $20^{\circ} \mathrm{C}$. Control bottles without animals were incubated at the same temperatures in order to find changes in the nutrient concentration due to other reasons than activity of animals. The soluble reactive phosphorus in water was estimated using standard molybdenum blue technique (Murphy and Riley, 1962) and photocolorimeter P-752.

Obtained empirical data on SRP excretion rates were presented as a regression (a power function) of the mass-specific SRP excretion rate versus body mass (mg dry mass) at habitat temperature. The mass-specific excretion rates of soluble reactive phosphorus were calculated as final minus initial SRP mass in water divided by dry mass of organisms per hour (SRP excreted rate, nmol.mg dry $\operatorname{mass}^{-1} \cdot \mathrm{h}^{-1}$ ). Total $\mathrm{P}$ flux rate mediated by benthic community $\left(\mu \mathrm{mol} \mathrm{P} \cdot \mathrm{m}^{-2} \cdot \mathrm{d}^{-1}\right.$ ) was calculated as a sum of $\mathrm{P}$ flux rate of each taxon for $24 \mathrm{~h}$ and average biomass of its population in the lake at each site and then at different areas (littoral and central part). To re-calculate lake-wide $P$ flux, we used proportion of areas for littoral (0-1 m depth) and central parts (>1 m depth) and mean values of P-flux in each zone of lake Donghu. 


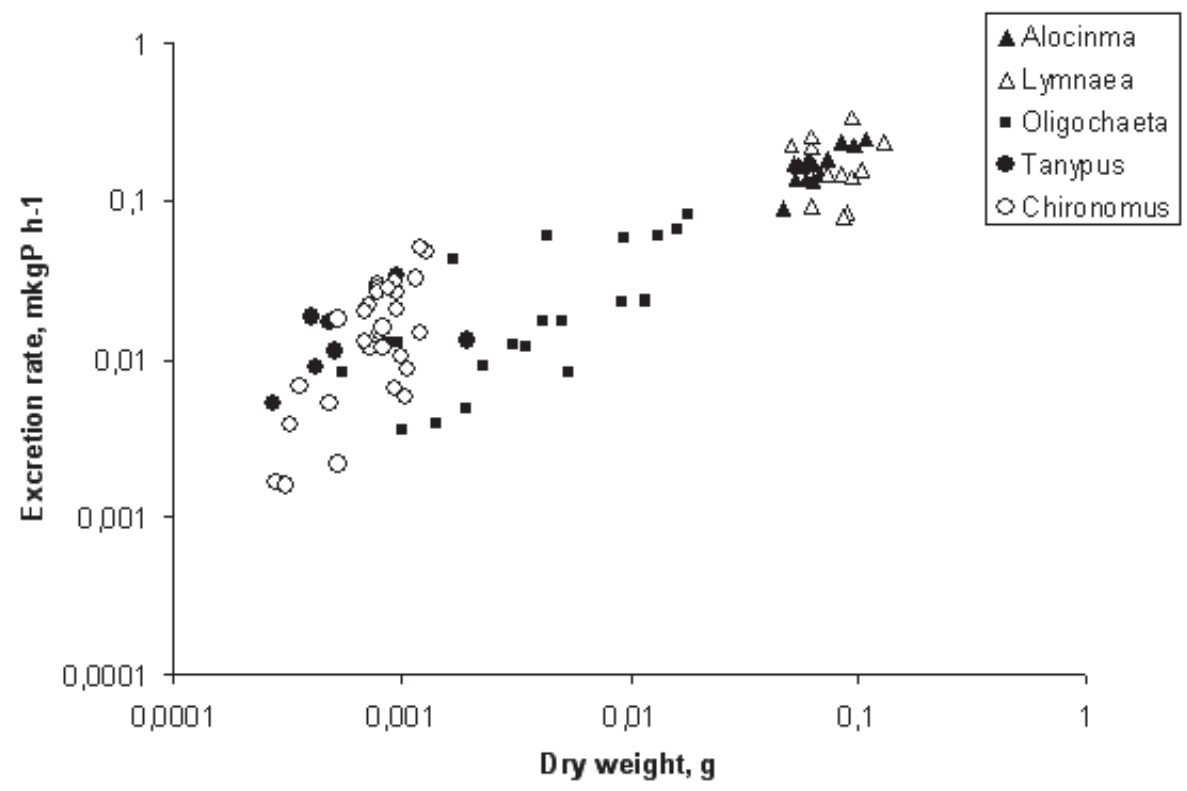

\section{Figure 2}

Dependence of individual excretion rate $\left(E x c R, \mu g P \cdot h^{-1}\right)$ on individual dry mass $(D W, g)$ for different taxa at $20^{\circ} \mathrm{C}$, approximated by a power function. Exc $=0.969 D W^{0.578}, N=84$, $R^{2}=0.77$. Filled square - Oligochaetes (Limnoodrilus hoffmeisteri), open circle - chironomid Chironomus plumosus, filled circle - chironomid Tanypus chinensis, open triangle - molluscs Alocinma longicornis, filled triangle - mollusk Lymnaea sp.

\section{Figure 2}

Dépendance des taux d'excrétion individuels $\left(E x c R, \mu g \mathrm{P} \cdot \mathrm{h}^{-1}\right)$ de la masse sèche individuelle $(D W, \mathrm{~g})$ pour les différents taxons à $20^{\circ} \mathrm{C}$, approchée par une fonction puissance. ExC $=0.969 D W^{0.578}, N=84$, $R^{2}=0,77$. Carré - oligochètes Limnoodrilus hoffmeisteri, cercle - chironomes Chironomus plumosus cercle plein - chironomes Tanypus chinensis, triangle - mollusques Alocinma longicornis, triangle plein - mollusque Lynmaea sp.

\section{RESULTS}

\section{> TAXONOMICAL COMPOSITION AND BIOMASS OF MACROZOOBENTHOS}

According to Wang (1996), in 1990s macrozoobenthos of lake Donghu consisted of 128 species. During our sampling in October 2009, several common taxa, such as mollusks (Gastropoda and Bivalvia), oligochaetes (Tubificidae and Naididae), hirudineans (Erpobdelidae and Glossiphoniidae), and aquatic insects (Chironomidae, Ceratopogonidae, Odonata and Coleoptera) were recorded in macrozoobenthos. List of benthic species found during sampling is presented in Table II. Species richness recorded in studied regions of lake Donghu varied reaching maximum 26 taxa in Guozhenghu, 24 taxa in Yujiahu and 6 taxa in Miaohu. The dominating taxa (>10-15\% of the total biomass) were: mollusks Alocinma longicornis, Lymnaea sp.; chironomids Chironomus plumosus, Tanypus chinensis, and oligochaetes Limnodrilus hoffmeisteri, Tubifex tubifex and Branchiura sowerbyi.

Significant differences in the total biomass were found between littoral and central sites in all studied lake regions ( $p<0.01$ in all cases, Figure 2). The lowest number of species (3 species) and the total biomass $\left(<0.2 \mathrm{~g} \cdot \mathrm{m}^{-2}\right)$ of zoobenthos were recorded in the most contaminated region (Miao). In other sites, the total biomass of macrozoobenthos varied between 10 and $160 \mathrm{~g} \cdot \mathrm{m}^{-2}$. Maximum biomass of macrozoobenthos was recorded in the shallow sites of Guozhenghu with depth $<1 \mathrm{~m}$ due to high contribution from mollusks and chironomids $(>80 \%$ to the total biomass, Table III). Oligochaetes were noticeably rare with maximum of $1 \mathrm{~g} \cdot \mathrm{m}^{-2}$ in Yujiahu (deepest site). 
Table II

List of benthic species detected in lake Donghu (October 2009).

Tableau II

Liste des espèces benthiques détectées dans le lac Donghu (octobre 2009).

\begin{tabular}{|c|c|c|c|}
\hline Species, taxa & Yujiahu & Miaohu & Guozhenghu \\
\hline $\begin{array}{l}\text { Mollusca } \\
\text { Alocinma longicornis (Benson) }\end{array}$ & + & & + \\
\hline Bellamya aeruginosa (Reeve) & + & & + \\
\hline Hippeutisc antori (Benson) & + & & + \\
\hline Lymnaea sp. & + & & + \\
\hline Parafossarulus striatulus (Benson) & & & + \\
\hline Anodonta woodiana woodiana (Lea) & & & + \\
\hline Sphaerium lacustre (Muller) & + & & + \\
\hline $\begin{array}{l}\text { Oligochaeta } \\
\text { Aulodrilus pluriseta (Piguet) }\end{array}$ & + & & + \\
\hline Branchiodrius hortensis (Stephenson) & & & + \\
\hline Branchiura sowerbyi Beddard & + & + & + \\
\hline Limnodrilus hoffmeisteri Claperede & + & + & + \\
\hline Rhyacodrilus sinicus (Chen) & + & & + \\
\hline Tubifex tubifex (Muller) & + & + & \\
\hline Naididae gen sp. & + & & + \\
\hline Eiseniella tetraedra (Savigny) & + & & + \\
\hline $\begin{array}{l}\text { Hirudinea } \\
\text { Erpobdella octoculata (Linnaeus }\end{array}$ & & & + \\
\hline Batracobdella paladosa (Carena) & & & + \\
\hline $\begin{array}{l}\text { Diptera } \\
\text { Chironomidae } \\
\text { Chironomus plumosus (Linnaeus) }\end{array}$ & + & & \\
\hline Chironomus sp. & + & + & + \\
\hline Einfeldia sp. & + & & \\
\hline Glyptotendipes sp. & + & & + \\
\hline Pelopia sp. & & & + \\
\hline Procladius choreus (Meigen) & + & + & + \\
\hline Tanypus chinensis (Wang) & + & & + \\
\hline T. punctipennis & + & + & + \\
\hline $\begin{array}{l}\text { Ceratopogonidae } \\
\text { Culicoides sp. }\end{array}$ & & & + \\
\hline Bezzia sp. & + & & \\
\hline Palmomyia sp. & + & & + \\
\hline $\begin{array}{l}\text { Coleoptera } \\
\text { Ecnomus tenellus Ramber }\end{array}$ & + & & + \\
\hline $\begin{array}{l}\text { Odonata } \\
\text { Libellula sp. } \\
\text { Coenagrion sp. }\end{array}$ & $\begin{array}{l}+ \\
+\end{array}$ & & + \\
\hline
\end{tabular}




\section{Table III}

Proportion of zoobenthic taxa biomass (\% of the total biomass) in different parts of lake Donghu.

Tableau III

Proportion de biomasse des taxons zoobenthiques (\% de la biomasse totale) dans différentes parties du Lac Donghu.

\begin{tabular}{|l|c|c|c|c|c|c|c|c|c|}
\hline Taxa & \multicolumn{3}{|c|}{ Yujiahu } & \multicolumn{3}{c|}{ Miaohu } & \multicolumn{3}{c|}{ Guozhenghu } \\
\hline & $<1 \mathrm{~m}$ & $2 \mathrm{~m}$ & $>3 \mathrm{~m}$ & $<1 \mathrm{~m}$ & $2 \mathrm{~m}$ & $>3 \mathrm{~m}$ & $<1 \mathrm{~m}$ & $2 \mathrm{~m}$ & $>3 \mathrm{~m}$ \\
\hline Chironomidae & 94.7 & 9.2 & 65.1 & 33 & 85.7 & 82.4 & 21.5 & 68.2 & 7.5 \\
\hline Hirudinea & - & - & - & - & - & - & 1.8 & - & - \\
\hline Ceratopogonidae & 5.1 & - & 1.9 & - & - & 5.81 & 0.1 & 14.1 & 2.0 \\
\hline Mollusca & - & 0.1 & - & - & - & - & 76.6 & 4.3 & 0.5 \\
\hline Oligochaeta & 0.2 & 90.7 & 33 & 67 & 14.3 & 11.8 & - & 13.4 & 90 \\
\hline
\end{tabular}

\section{Table IV}

Mass-specific excretion rates of soluble reactive phosphorus (AVG $\pm S E$ ) for different taxa $\left(n \mathrm{~mol} P\right.$ excreted per $\mathrm{mg}$ dry $\left.\cdot \mathrm{mass}^{-1} \cdot \mathrm{h}^{-1}\right)$ obtained experimentally at $20^{\circ} \mathrm{C}$ temperature. $\mathrm{N}-$ number of experimental series.

Tableau IV

Les taux d'excrétion masse spécifique de phosphore réactif soluble (AVG $\pm \mathrm{SE}$ ) pour différents taxons (nmol $\mathrm{P}$ excrété par $\mathrm{mg}$ de masse sèche ${ }^{-1} \cdot \mathrm{h}^{-1}$ ) obtenus expérimentalement à $20^{\circ} \mathrm{C}$ de température. $N-$ nombre de séries expérimentales.

\begin{tabular}{|l|c|c|c|}
\hline Taxon & $n$ & $D W, \mathrm{mg}$ & $P_{\text {exc }} \eta \mathrm{mol} \cdot \mathrm{mg}$ dry $\mathrm{mass}^{-1} \cdot \mathrm{h}^{-1}$ \\
\hline Alocinma & 15 & $62.05 \pm 3.83$ & $0.09 \pm 0.006$ \\
\hline Lymnaea & 12 & $82.9 \pm 6.3$ & $0.07 \pm 0.01$ \\
\hline Mollusca & 27 & $71.39 \pm 3.74$ & $0.08 \pm 0.005$ \\
\hline Limnodrilus & 13 & $7.7 \pm 1.65$ & $0.14 \pm 0.03$ \\
\hline Chironomus & 29 & $0.79 \pm 0.05$ & $0.67 \pm 0.07$ \\
\hline Tanypus & 15 & $0.71 \pm 0.22$ & $0.86 \pm 0.16$ \\
\hline Chironomidae & 44 & $0.77 \pm 0.06$ & $0.71 \pm 0.06$ \\
\hline
\end{tabular}

\section{> SRP EXCRETION RATE AND PHOSPHORUS FLUX}

An direct relationship was observed between the individual excretion rates and the mean individual mass of animals, when the excretion rate was increasing with body mass increasing (Figure 2). These relationships were approximated by a power function:

$$
E x c=0.969 D W^{0.578}, n=84, R^{2}=0.77,
$$

where Exc $\left(\mu \mathrm{g} \mathrm{P} \cdot \mathrm{h}^{-1}\right)$ - excretion rate, $D W(\mathrm{~g})$ - individual dry mass of different taxa. It is combined excretion rate for studied taxa (oligochaetes, chironomids, and mollusks) at temperature $20^{\circ} \mathrm{C}$.

The average body mass and mass specific excretion rates of studied animals differed significantly between taxa (all $p<0.05$; Table IV). Chironomids tended to excrete SRP at significantly higher rates than oligochaetes and mollusks (all $p<0.01$ ). Mollusks tended to 

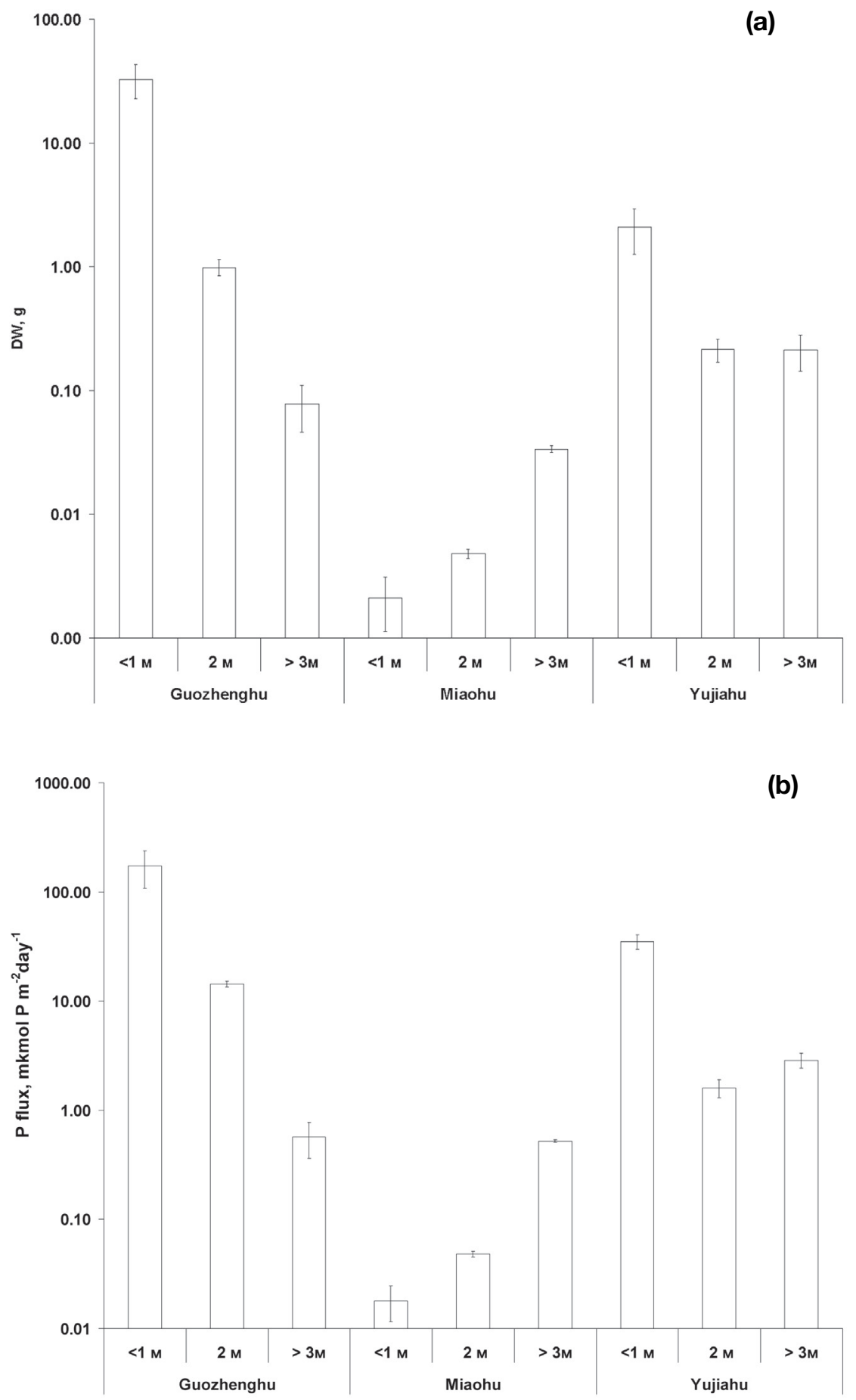

Figure 3

Total biomass (a) and P flux (b) of zoobenthos in studied parts of lake Donghu.

\section{Figure 3}

Biomasse totale du zoobenthos (a) et flux de $\mathrm{P}$ (b) dans les régions étudiées du lac Donghu.

have lowest SRP excretion rate as a result of highest body mass of the animals because of massive shell.

Phosphorus fluxes by benthic invertebrate excretion varied between sites (littoral and central). The extremely low biomass of macroinvertebrates was recorded in all sites of Miaohu $(<0.01 \mathrm{~g}$, Figure 3a). Phosphorus flux by benthic communities was also very low $\left(<1 \mu \mathrm{mol} \mathrm{P} \cdot \mathrm{m}^{-2} \cdot\right.$ day $^{-1}$, 


\section{Table $V$}

Benthic biomass (dry mass) distribution and SRP excretion rates of benthic animals: lake Donghu (AVG \pm SE).

Tableau $\mathrm{V}$

Distribution de la biomasse benthique (masse sèche) et des taux d'excrétion SRP des animaux benthiques dans le lac Donghu (moyenne \pm SE).

\begin{tabular}{|l|c|c|}
\hline Lake part/ regions & Biomass, $\mathrm{g} \cdot \mathrm{m}^{-2}$ & $\mathrm{P}$ flux, $\mathrm{\mu mol} \mathrm{P} \cdot \mathrm{m}^{-2} \cdot \mathrm{day}^{-1}$ \\
\hline Littoral & $32.8 \pm 9.9$ & $173.0 \pm 64.4$ \\
Guozhenghu & $0.002 \pm 0.001$ & $0.02 \pm 0.01$ \\
Miaohu & $2.1 \pm 0.8$ & $35.3 \pm 5.4$ \\
Yujiahu & $11.6 \pm 3.6$ & $69.5 \pm 23.3$ \\
average & $0.5 \pm 0.1$ & $7.5 \pm 0.6$ \\
\hline Central & $0.02 \pm 0.001$ & $0.3 \pm 0.01$ \\
Guozhenghu & $0.21 \pm 0.06$ & $2.2 \pm 0.4$ \\
Miaohu & $0.24 \pm 0.05$ & $3.4 \pm 0.3$ \\
Yujiahu & 3.6 & 23.2 \\
average & \multicolumn{2}{|}{} \\
\hline Lake-wide & & \\
\hline
\end{tabular}

Figure 3b). The phosphorus flux was the highest at littoral site of Guozhenghu $\left(173 \mu \mathrm{mol} \mathrm{P} \cdot \mathrm{m}^{-2} \cdot\right.$ day $\left.^{-1}\right)$, intermediate $\left(35.3 \mu \mathrm{mol} P \cdot \mathrm{m}^{-2} \cdot \mathrm{day}^{-1}\right)$ at the littoral of Yujiahu part and lowest at the deepest site of Yujiahu $\left(2.2 \mu \mathrm{mol} \mathrm{P} \cdot \mathrm{m}^{-2} \cdot\right.$ day $^{-1}$, Table V). It averaged at $69.5 \mu \mathrm{mol}$ $\mathrm{P} \cdot \mathrm{m}^{-2} \cdot$ day $^{-1}$ in littoral zone that was almost twenty times greater than in central sites of the lake $\left(3.4 \mu \mathrm{mol} P \cdot \mathrm{m}^{-2}\right)$. Chironomids were the main contributor to the phosphorus excretion reaching maximum $120 \mu \mathrm{mol} \mathrm{P} \cdot \mathrm{m}^{-2} \cdot$ day $^{-1}$ in littoral site of Guozhenghu and $33 \mu \mathrm{mol} P \cdot \mathrm{m}^{-2} \cdot \mathrm{day}^{-1}$ in Yujiahu. Also, littoral mollusks excreted noticeable part of SRP $\left(48.2 \mu \mathrm{mol} \mathrm{P} \cdot \mathrm{m}^{-2} \cdot\right.$ day $\left.^{-1}\right)$ in Yujiahu. Oligochaetes contributed $30-90 \%$ to the total flux by benthic animals in central part of Miaohu and Yujiahu while the total flux in these sites was low $\left(0.3-2.2 \mu \mathrm{mol} \mathrm{P} \cdot \mathrm{m}^{-2} \cdot \mathrm{day}^{-1}\right.$, Table V).

\section{DISCUSSION}

The invertebrate taxa differed in spatial distribution probably as a result of change in chemical conditions, primarily in oxygen content, in near the bottom habitats. Zoobenthos (chironomids and oligochaetes) was not abundant in central parts of lake Donghu, which were periodically hypoxic during summer and early autumn. The lake Donghu benthic community is typical for eutrophic lake and is dominated by chironomids and oligochaetes (Jonasson, 1984; Devine and Vanni, 2002). In general, we find distribution patterns similar to those reported by previous studies (Chen and Wu, 1990; Wang, 1996; Gong et al., 2000). Differences in composition of benthic communities detected in studied sites may be a result of different oxygen and phosphorus availabilities. Miaohu is most polluted area in the lake, this fact may explain the very poor species number in community with dominance of oxygen-tolerant taxa as oligochaetes.

Inverse relationships between SRP excreted rate and body mass of organisms are confirmed in this study as well as by other empirical data for different taxa: fish, zooplanktonic and benthic organisms (Johannes, 1964; Gutelmakher, 1977; Oude and Gulati, 1988; Schindler and Eby, 1997; Griffiths, 2006). We find interspecies differences in individual SRP excretion rates within family Chironomidae (Table $V$ ) such as Chironomus plumosus $(0.67 \pm 0.07$ $\eta \mathrm{mol} \cdot \mathrm{mg}$ dry mass ${ }^{-1} \cdot \mathrm{h}^{-1}$ in the case $0.79 \pm 0.05 \mathrm{mg}$ of dry body mass) collected from shallow sites and Tanypus chinensis $\left(0.71 \pm 0.22 \mathrm{\eta mol} \cdot \mathrm{mg}\right.$ dry mass ${ }^{-1} \cdot \mathrm{h}^{-1}$ in the case $0.86 \pm 0.16 \mathrm{mg}$ 
of dry body mass) from central sites $\left(20^{\circ} \mathrm{C}\right)$. Most likely, differences in specific metabolic rates could be related to differences in SRP excretion rate of species. Interspecies differences in SRP excretion rates were found also in other studies: between the rotifera Euchlanis dilatata $\left(18-19^{\circ} \mathrm{C}\right)$ and other rotifers (Gulati et al., 1989) as well as between Dreissena polymorpha and D. bugensis (Conroy et al., 2005). At the same time, Devine and Vanni (2002) showed that differences in SRP excretion rate between taxa are not significant and this rate depend mostly on temperature and biomass. Also, it probably might be a result of difference in food resources accumulated in littoral and deepwater sites of the lake, but this question needs future research.

The SRP excretion rate by Tubificidae (Oligochaeta) in this study (Table IV) is similar with the data for the same taxa at the similar exposition time $(4 \mathrm{~h})$ and temperature $10^{\circ} \mathrm{C}$ estimated by Fukuhara and Sakamoto (1987). At the same time, the excretion by Chironomidae from lake Donghu was twice time bigger than in other study with the same exposition time and temperature $\left(0.35 \mathrm{\eta mol} \cdot \mathrm{mg}\right.$ dry $\mathrm{mass}^{-1} \cdot \mathrm{h}^{-1}$, Fukuhara and Sakamoto, 1987). Excretion in natural conditions may be affected by food egestion rates that are different between studied taxa and depend also on food availability in habitats.

Water temperature is the main determinant of the basal metabolic rate and can exert an influence on SRP excretion activity. Several works confirm that specific benthic community SRP excretion rates increasing with temperature. These relationships cause the summer and winter (seasonal) differences in phosphorus fluxes as in the case of zooplankton (Oude and Gulati, 1988) and benthic communities (Devine and Vanni, 2002; Postolache et al., 2006). These variations in SRP excretion rates are not only relate to characteristics of individual species/taxa but also reflect the character of environments and primarily trophic conditions in each case study.

According to Jiang and Shen (2006), the total direct release rates of phosphorus from sediments vary in different part of lake Donghu from 0.81 to $8.60 \mathrm{mg} \mathrm{P} \cdot \mathrm{m}^{-2} \cdot \mathrm{d}^{-1}$ (or 2-277 $\mu \mathrm{mol} \mathrm{P} \cdot \mathrm{m}^{-2} \cdot \mathrm{d}^{-1}$ ) averaging at $1.99 \mathrm{mg} \mathrm{P} \cdot \mathrm{m}^{-2} \cdot \mathrm{d}^{-1}$ or $64 \mu \mathrm{mol} \mathrm{P} \cdot \mathrm{m}^{-2} \cdot \mathrm{day}^{-1}$. We estimate phosphorus excretion rates by benthic invertebrate in $36 \%$ of the total direct release from bottom sediment to water after Jiang and Shen (2006). At the same time, estimated in littoral site of Guozhenghu, maximum SRP excretion rate from benthos $\left(173 \mu \mathrm{mol} P \cdot \mathrm{m}^{-2} \cdot \mathrm{d}^{-1}\right)$ is a major portion $(62 \%)$ of the maximum total phosphorus release in this lake. Other studies also show that contribution of SRP excretion by benthic animals to the total phosphorus release is very important and is usually varying between 4 and $17 \%$ (Andersson et al., 1988; Devine and Vanni, 2002; Postolache et al., 2006). Furthermore, in dry years with low phosphorus input from watershed phosphorus excretion mediated by animals can reach maximum $90 \%$ of the total phosphorus release (Devine and Vanni, 2002).

Maximum $70-90 \%$ of phosphorus was released in lake Donghu from the activity of chironomids. Contribution of tubificids to the total $\mathrm{P}$ flux by benthos was $33-90 \%$ with maximum in central sites. In Lake Acton (south-western part of Ohio, USA), phosphorus fluxes are also determined by excretion of chironomids and tubificids in oxic sites while P fluxes in anoxic were determined by excretion of Chaoborus (Devine and Vanni, 2002).

SRP excretion rate mediated by animals (like-wide excretion rate $-23.2 \mu \mathrm{mol} \mathrm{P} \cdot \mathrm{m}^{-2} \cdot \mathrm{day}^{-1}$ at $T=20^{\circ} \mathrm{C}$ ) is close to $\mathrm{P}$ flux via benthic community in another eutrophic ecosystem Lake Acton (lake-wide excretion rate $-16.7 \mu \mathrm{mol} \mathrm{P} \cdot \mathrm{m}^{-2} \cdot$ day $^{-1}$ at $T=20^{\circ} \mathrm{C}$, according to Devine and Vanni, 2002). In both compared lakes, the highest rate of the $P$ flux was recorded in littoral and the lowest in central sites.

Difference in SRP flux between central and littoral sites in small lakes is obviously as a result of spatial differences in physical and chemical characteristics together with structure and biomass of zoobenthos. The role of animals in phosphorus release may be very low during period of hypoxia which induced often by warm summer weather in water near bottom in the central part of eutrophic lakes, such as lake Donghu. In this case, direct release from sediments to water becomes a main source of this macronutrient.

We found that bulk of biomass in lake Donghu concentrated in littoral sites (littoral biomass: central biomass as $48: 1$, Table V) in spite of littoral contributes significantly less part (30\%) 
than central sites. In this lake, it appears that the phosphorus fluxes via benthic invertebrate excretion were 20 times greater at littoral sites than in central sites. Probably, in central sites with temporal hypoxic/anoxic phenomena, direct release of phosphorus from sediments exceeds the release from benthic invertebrates.

\section{CONCLUSION}

Our results show the important contribution of benthic invertebrate excretion to the total $P$ flux from sediments to water especially in oxic zone of eutrophic lake. We find significant differences in excretion rate both between taxa and between studied sites. Rate of phosphorus excretion depends directly on biomass and on the specific SRP excretion rates of benthic animals. The specific SRP excretion rates might change with water temperature (seasonally) and type of habitats (spatially). Variability in P flux may be notable in lakes with high importance of littoral zone or in small shallow lakes with food web structure that is irregular and changes over the time. We conclude that benthic animals (especially chironomids) represent an important link in benthic-pelagic coupling in eutrophic shallow lakes. The input of benthic invertebrates in phosphorus cycling might be compared to other sources of phosphorus known to be important such as phosphorus inputs from watersheds and from sediments via microbial processes.

\section{ACKNOWLEDGEMENTS}

We thank Prof. Alexander Alimov for helpful discussion, Ms. Lada Denisova for important comments and suggestions to first version of the manuscript, and students Daizhong Huang, Wenjuan Xiao, Xi Chen, Jie Hou (Graduate School, Chinese Academy of Sciences) for help with laboratory measurements. This work presents results of the Sino-Russian cooperation between Laboratory of Biochemistry (Chinese Academy of Sciences, Institute of Hydrobiology, Wuhan, China) and Laboratory of Freshwater Biology (Russian Academy of Sciences, Zoological Institute, St. Petersburg, Russia). The study was supported by the National Science Foundation of China (projects 40730528, 40911120038) and by the Russian Foundation for Basic Research (project 08-04-92217-GFEN_a).

\section{REFERENCES}

Andersson G., Granéli W. and Stenson J., 1988. The influence of animals on phosphorus cycling in lake ecosystems. Hydrobiologia, 170, 267-284.

Cao X., Strojsová A., Znachor P. and Zapomelová E., 2005. Detection of extracellular phosphatases in natural SRPing phytoplankton of a shallow eutrophic lake (Donghu, China). Eur. J. Phycol., 40, 251-258.

Chen Q. and Wu T. 1990. Zoobenthos. In: Liu J. (ed.), Ecological studies on Donghu Lake, Vol. 1, Science Press, Beijing, 129-151 (in Chinese).

Conroy J.D., Edwards W.J., Pontius R.A., Kane D.D., Zhang H., Shea J.F., Richey J.N. and Culver D.A., 2005. Soluble nitrogen and phosphorus excretion of exotic freshwater mussels (Dreissena spp.): potential impacts for nutrient remineralisation in western lake Erie. Freshw. Biol., 50, 1146-1162.

Devine J.A. and Vanni M.J., 2002. Spatial and seasonal variation in nutrient excretion by benthic invertebrates in a eutrophic reservoir. Freshw. Biol., 47, 1107-1121.

Feuillade J., Feuillade M. and Blanc P., 1990. Alkaline phosphatase activity fluctuations and associated factors in a eutrophic lake dominated by Oscillatoria rubescens. Hydrobiologia, 207, 233-240.

Fukuhara H. and Sakamoto M., 1987. Enhancement of inorganic nitrogen and phosphate release from lake sediment by tubificid worms and chironomid larvae. Oikos, 38, 312-320.

Gillor O., Hadas O., Post A.F. and Belkin S., 2002. Phosphorus bioavailability monitoring by a bioluminescent cyanobacterial sensor strain. J. Phycol., 38,107-115. 
Gong Z., Xie P. and Wang S., 2000. Macrozoobenthos in 2 shallow, mesotrophic Chinese lakes with contrasting sources of primary production. J. N. Amer. Benthol. Soc., 19, 709-724.

Griffiths D., 2006. The direct contribution of fish to lake phosphorus cycles. Ecol. Freshw. Fish, 15, 86-95.

Gulati R.D., Ejsmont-Karabin J., Rooth J. and Siewertsen K., 1989. A laboratory study of phosphorus and nitrogen excretion of Euchlanis dilatata lucksiana. Hydrobiologia, 186-187, 347-354.

Gutelmakher B.L. 1977. Quantitative estimation of zooplankton role in phosphorus cycling in a lake. Zhurnal Obshej Biologii, 38, 914-921 (in Russian).

Huang X., 1996. The process of Regressive Succession of Ecosystem of the Donghu Lake and its Ecological effects. In: Liu J.K. (ed.), Ecosystem research of lake Donghu, Science Press, Beijing, 35-72.

Jiang J.G. and Shen Y.-F., 2006. Development of the microbial communities in lake Donghu in relation to water quality. Environ. Monitor. Assess., 127, 227-236.

Johannes R.E., 1964. Phosphorus excretion and body size in marine animals: microzooplankton and nutrient regeneration. Science, 146, 923-924.

Jonasson P.M., 1984. Oxygen demand and long-term changes of profundal zoobenthos. Hydrobiologia, $115,121-126$.

Li Z., Liang X., Chen X., Lei Z. and Tan Y., 1996. Status of the water chemistry of the Donghu Lake. In: Liu J.K. (ed.), Ecosystem research of lake Donghu, Science Press, Beijing, 73-90.

Murphy J. and Riley J.P., 1962. A modified single solution for the determination of phosphate in natural waters. Anal. Chim. Acta, 27, 31-36.

Oude P.J. and Gulati R.D., 1988. Phosphorus and nitrogen excretion rates of zooplankton from the eutrophic Loosdrecht lakes, with notes on other $\mathrm{P}$ sources for phytoplankton requirements. Hydrobiologia, 169, 379-390.

Postolache C., Geta Risnoveanu G. and Vadineanu A., 2006. Nitrogen and phosphorous excretion rates by tubificids from the Prahova river (Romania). Hydrobiologia, 553, 121-127.

Schindler D.E. and Eby L.A., 1997. Stoichiometry of fishes and their prey: implications for nutrient recycling. Ecology, 78, 1816-1832.

Spijkerman E. and Coesel P.F.M., 1998. Alkaline phosphatase activity in two planktonic desmid species and the possible role of an extracellular envelope. Freshw. Biol., 39, 503-513.

Tarvainen M., Ventela A.-M., Helminen H. and Sarvala J., 2005. Nutrient release and resuspension generated by ruffe and chironomids. Freshw. Biol., 50, 447-458.

Vanni M.J., 2002. Nutrient cycling by animals in freshwater ecosystems. Annu. Rev. Ecol. Syst., 33, 341-370.

Vanni M.J., Renwick W.H., Headworth J.L., Auch J.D. and Schaus M.H., 2001. Dissolved and particulate nutrient flux from three adjacent agricultural watersheds: a five-year study. Biogeochemistry, 54, 85-114.

Vrba J. and Machacek J., 1994. Release of dissolved extracellular b-N-acetylglucosaminidase during crustacean molting. Limnol. Oceanogr., 39, 712-716.

Wang S., 1996. The effects of eutrophication on the diversity of zoobenthos in lake Tunghu, Wuch-ang. Acta Hydrobiologica Sinica, 20, 73-89 (in Chinese).

Wang S., Gong Z. and Xie P., 2000. Environmental factors and the succession of aquatic insects in a shallow Chinese lake. Bull. Environ. Contam. Toxicol., 64, 701-707.

Wilhelm F.M., Hudson J.J. and Schindler D.W., 1999. Contribution of Gammarus lacustris to phosphorus recycling in a fishless alpine lake. Can. J. Fish. Aquat. Sci., 56, 1679-1686.

Xie P., 2006. Biological mechanisms driving the seasonal changes in the internal loading of phosphorus in shallow lakes. Science in China Series D Earth Sciences, 49, 14-27. 